\title{
CAPITAL STRUCTURE AND CULTURE IN MALAYSIA: A STUDY FROM ETHNICITY AND RELIGION PERSPECTIVES
}

\author{
Shu Geok Ooi ${ }^{1, *}$, and Ei Yet Chu ${ }^{1}$ \\ ${ }^{1}$ Graduate School of Business, Universiti Sains Malaysia, Penang, Malaysia
}

ABSTRACT - Conceptualization from New Institutional Economics of Williamson (2000), the study looked at the issue of formal and informal institutional factors on financial decision making. This study first investigated the informal embedded culture such as "ethnicity and religion" that could influence the decision in a firm's capital structure. Secondly, the influence of culture informal institutions such as "Shariah and Non-Shariah compliant firms on capital structure decisions was investigated. Previous observations showed Chinese have high individualism and low uncertainty avoidance. Whereas, the Malay has low individualism and high uncertainty. These dimensions affect firm's decision behaviour towards capital structure decision. This study aimed to confirm whether culture could explain trade-off and pecking order theory of capital structure decision. The study adopted a New Institutional Economics framework to understand how cultural divergence rationality interferes on caporal structure decision, where traditional finance only emphasises on economic responsibility that strives resources maximization. The study applied a longitudinal approach, where 187 sample firms of data covering a sample period from 2015 to 2019 . The firms consisted of Bursa 90 best corporate governance firms awarded by Minority Shareholders Watch Group (MSWG) in 2017 and 2018; also randomly selected 97 PLCs of non-winner firms where both panels data balance in term of Board independence and Number of Shariah Compliance PLCs. A secondary data collection approach was adopted to obtain the CEO's ethnicity and religion. Data from the extract of an annual report and Shariah-compliant list were adopted. This study made significant contributions to explain the relationships of informal (culture as ethnicity and religion) on capital structure; formal institution (policies as firm's shariah compliance) on capital structure decision.

\author{
ARTICLE HISTORY \\ Received: $15-9-2020$ \\ Accepted: 1-12-2020
}

\section{KEYWORDS}

Cultural Finance;

Capital Structure;

New Institutional

Economics;

Ethnicity;

Religion;

Shariah-Compliant;

Corporate Governance

\section{INTRODUCTION}

The study of cultural finance has increased over the last ten years. Culture and finance seem to be mutually exclusive subjects, which may not affect one another. However, since the introduction of culture dimension by Hofstede (1983), studies of culture on business practices witnessed the rise of interest such as business performance, compensation practices, cross-border acquisition performance, managerial attitude, and job outcome (Aggarwal, Faccio, Guedhami, \& Kwok, 2016). On the other hand, cultural issue on capital structure is completely silent. Breuer and Quinten (2009) concluded that many previous studies on cultural finance lack a theoretical framework to support the construct between culture and capital structure. The previous researchers suggested the establishment of cultural finance as an autonomous discipline to conduct further study, and the ideal way to position cultural finance is between the spectrum of social science and finance. Despite this claim, the discipline of cultural finance is still young and unstructured, and the theory to explain the context of cultural finance is still opaque rather than clearly defined (Nadler \& Breuer, 2019).

This study echoed the call from Nadler and Breuer (2019) to adopt Williamson's New Institutional Economics (NIEs) as a standardized theoretical framework for future study of cultural finance. Williamson (2000) reiterated that culture and governance could lead to lower transaction costs and subsequently enhance the firm value. There are four levels of transaction cost economics. The first level is the culture embedded at informal institutions. The second level of transaction economics is formal institutions such as policies and regulations. The third level consists of governance mechanism transaction economics and the fourth level is the firms' capital structure decision transaction economics. Hence, NIEs link the transaction cost from informal institutions (Culture), formal institutions (Policies and Regulations), and governance to decision making and it opens the new avenue to study cultural finance.

In 2018, Malaysia Non-Financial Corporate debt recorded at 103.7\% of GDP (Bank Negara Malaysia, 2019), which illustrate that Malaysia is among the top three risk seeking economies after Hungary and China (Bank Negara Malaysia, 2015). The IMF has raised its concern in the recent assessments postulated that the risks arising from rising debt are surpassing levels recorded prior to the global financial crisis. If Malaysia has had high debt in the past based on historical trend, and if firms' capital structure decision moves towards "risk-seeking" which could cause higher debt burdens, it could increase the propensity to default from vulnerable firms, inflicting credit losses and funding pressures on financial intermediaries to key economic sectors. Consequently, it may precipitate a severe economic slowdown. 
Conceptualize from NIEs of Williamson (2000), this research looked at the issue of a firm's capital structure decision on the trade-off theory or pecking order theory from formal and informal institutional factors. This study first investigated the informal embedded culture such as "ethnicity and religion" which could influence the decision in a firm's capital structure, the first level of NIEs framework. Secondly, the influence of culture in formal institutions such as "Shariah and Non-Shariah compliant firms on capital structure decisions, the second level of NIEs was also investigated. Thirdly, the study looked at the transaction cost economics affect firm's decision behavior towards capital structure decision. The study aimed to confirm whether culture could explain the trade-off and pecking order theory of capital structure decision

\section{LITERATURE REVIEW}

Culture studies are not new, researchers have defined culture differently in a broad spectrum where it has impacted many aspects of life. For instance, Kroeber and Kluckhohn (1952) concluded culture as explicit and implicit patterns for behavior that transmits based on symbols that belong to distinctive achievements of human groups, including artifacts; beliefs; ideas, and especially values; culture climate as an outcome of an action. Similarly, a profound researcher of culture, Hofstede defined culture as the collective programming of the mind that leads to patterned ways of thinking, feeling, and acting that distinguish the members of the group of a category of people from others (Hofstede, 1983). On the other hand, Williamson (2000) conceptualized the culture is embedded at informal institutions where norms, customs, traditions are influenced by religion, yet the cultural change is slow. Likewise, studies postulated that culture is a set of beliefs and values that influence individuals; perceptions, decisions, preferences, and behaviors that influence capital structure decisions (Nadler \& Breuer, 2019). Hence, this study synthesized the culture is embedded at informal institutions (Williamson, 2000) that distinguish from others group (Hofstede, 1983) and form a set of beliefs and values that influences the pattern of behaviors that influence decision-making (Nadler \& Breuer, 2019).

Culture has embedded the beliefs and values that influence the pattern of behaviors at different depths (Spencer-Oatey \& Franklin, 2012). First, understanding culture through observable artifacts like custom; dress code; architecture; manner; ritual ceremony, and emotional intensity is needed. The visible artifacts are easy to obtain and can describe "how" people behave to construct the environment and "what" behavior are manifested among them. However, a visible artifact cannot give the reason "why" people behave in such a manner. Secondly, the understanding of culture in the context of values is explored. For instance, values are formed according to reinforce statements made by someone as reasons for guiding principles and behaviors. Hence, values give an understanding of "why" people behave and making such a decision. Thirdly, the action of behaviors continues to solve problems and the values gradually transform into an underlying assumption. When cognitive processes repeatedly work successfully, it reduces the awareness and becomes unconscious for a long period of time within the members of a distinctive group, then the culture is gradually formed (Spencer-Oatey \& Franklin, 2012). The previous researchers articulated that espoused values that embedded in culture, are the interaction point between "what and how people behave", such as firm's philosophy; mission statement; and core values, and "why people behave", such as business decision making.

When culture influence decision making, it sieves an individual's preferences, values, and beliefs for making a decision. However, the aforesaid cultural influences are labeled as indirect by Spencer-Oatey and Franklin (2012). For instance, when the size of the pores is large, it is flexible and fewer constraints for decision making, whereas the pore size is small, it is more rigid and has more constraints to make the same decision. Hence, some culture is liberal, and some have more restrictions such as forbidden and taboo, but both impacts the decision making as a whole. Nevertheless, culture, on one hand, can be observed in accordance to visible artifacts but flipping over culture and value become opaque after transforms into underlying assumptions that eventually become unconscious (Spencer-Oatey \& Franklin, 2012). Thus, the divergence of culture across all dimensions make the cultural finance discipline more challenging to conduct research. Likewise, the previous researchers acknowledge that study culture in finance has various challenges such as culture is abstract, fuzzy, and difficult to construct (Williamson, 2000).

The diverse perspective to study culture on finance whether, from nationals, institutions, and individuals perspectives, many are without clear theory nor theoretical framework (Nadler \& Breuer, 2019). For instance, from the individual perspective, Grinblatt and Keloharju (2001) documented that investors are more likely to hold, buy, and sell the stocks that are geographically proximate to the investor, share the same native tongue, and have CEOs of the same cultural background. Similarly, Landa (2008) reiterated individual or group identity transmit information to potential trading partners, and erect barriers of entry for those outsiders to associate and benefit from the group. Conversely, when examining the influence of culture on a firm's dimension, Boubakri and Saffar (2016) found that firms' ability to overcome financial constraints is affected by culture when access to finance is challenging. Nonetheless, Giannetti and Yafeh (2012) postulated that cultural differences between professional decision-makers affect financial contracts in a large dataset of international syndicated bank loans. The previous researchers discovered that cultural distance leads banks to offer borrowers lower loans at higher rates and are more likely to require collateral or guarantees. Furthermore, looking at the culture on the national dimension, Ahern, Daminelli, and Fracassi (2015) found a piece of strong evidence that three key dimensions of national culture (trust, hierarchy, and individualism) affect merger volume and synergy gains. Similarly, El Ghoul and Zheng (2016) articulated that international trade liberalization mitigates the impact of domestic culture on trade credit provision. Despite the theoretical links between the measurement of culture on finance are opaque (Breuer $\&$ Quinten, 2009), Nadler and Breuer (2019) advocated adopting NIEs for cultural finance study. 
The unclear theoretical link of cultural finance causes many previous studies to not revisit the theory yet produce pronounced empirical observations (Nadler \& Breuer, 2019). Instead of theory, NIEs theoretical framework postulated by Williamson was behind many studies of culture on capital structure decision (Boubakri \& Saffar, 2016; El Ghoul \& Zheng, 2016). For instance, the idea to adopt Williamson's NIEs to study culture on capital structure is strongly supported by Nadler and Breuer (2019). Likewise, the ideology of familiarizing the NIEs theoretical framework is supported by Aggarwal, Faccio, Guedhami, and Kwok (2016). Hence, Williamson (2000) NIEs reiterated that cultural factors have intrinsic values to exert influence on preferences of an individual's capital structure decision-making whether they are "risk-seeking" or "risk-averse". Similarly, formal institutions of a society and CG simultaneously influence the economic decision of an individual. Furthermore, Williamson (2000) articulated that informal institutions embedded cultural constraints like norms, beliefs, and values, and formal institutions like policies and regulations have imposed rules and boundaries to legitimate the transaction cost. Furthermore, the governance system compares the internal and external transaction costs to minimize agency influence on capital structure decisions. Therefore, an informal institution (Ethnicity and Religion); formal institutions (Policies and Regulations); and governance impact on capital structure, are illustrated in Figure 1.

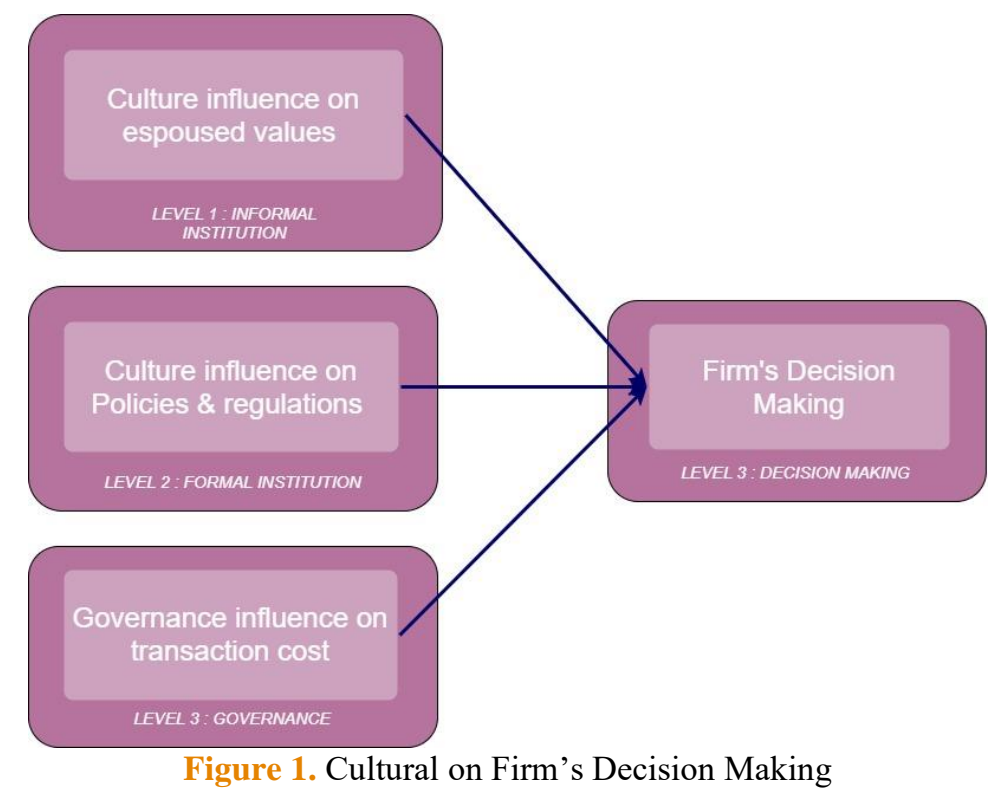

The conceptual framework is supported in the respective theories wherein institutional constraints, the managers make decisions based on the comparison of transactions cost incur from internal firm structure or external source. Therefore, transaction cost determines capital structure decisions on capital structure (Williamson, 2000). Apart from TCE, the earlier literature reviews showed theorists of cultural finance lean towards pecking-order theory and trade-off order theory.

Observation showed that non-family firms rely heavily on debt, in contrast with family-controlled firms which are mobilizing internal funds and reduce dependency on debt. This confirms that pecking-order constraints exist in family firms (Chu, Lai, \& Song, 2016). On the other hand, observations showed that asymmetric information has a significant impact on firms' short-term and total capital structure (Newman, Gunessee, \& Hilton, 2012). Other observations showed the variables of growth opportunity and CG in general influence the variation of the capital structure and yet the capital structure of firms was significantly related to the firm performance (Mallisa \& Kusuma, 2017). Therefore, profound CG can minimize transaction costs and increase organizational efficiency and performance (Williamson, 1993). On the other hand, observations showed that total debt to total equity has an inverse impact with firm value, supporting the trade-off order theory. Although there are benefits of debts, conversely there are also the costs of debts to be considered. The cost of debt increases alongside the increase of the bankruptcy probability as debt requires firms for periodic repayment (Chaleeda, Islam, Ahmad, \& Ghazalat, 2019). Moreover, culture can have an impact on uncertainty or certainty preferences, distinguishing between risk-averse and risk-seeking decision making (Albaity \& Rahman, 2012; Hilary \& Hui, 2009; Hsee \& Weber, 1999).

\section{Cultural and Finance on Decision Making in Malaysia}

The study of cultural finance in Malaysia can be dated back to 2002, Haniffa and Cooke (2002) investigated the impact of cultures such as religion and ethnic group on voluntary disclosures which are non-mandatory and non-accounting information required by BURSA in Malaysia. For instance, the results showed that positive associations between two CG variables were chaired by a non-executive director and domination of family members on boards, and the extent of voluntary disclosure (Haniffa \& Cooke, 2002). Similarly, another study by Haniffa and Cooke (2002) were focused on the impact of culture and governance in corporate social reporting. Findings showed a significant relationship between corporate social disclosure and boards was dominated by Malay directors, boards dominated by executive directors, 
chaired with multiple directorships, and foreign share ownership (Haniffa \& Cooke, 2005). However, they made significant contributions to the cultural finance discipline that focuses on culture such as religion and ethnicity rather than cultural dimensions articulated by Hofstede (1983).

Although Malaysia is a multiracial society, only a few studies focused on religion and ethnicity compared to dimensional culture on the financial decision. For example, ethnicity impact on tax policy (Mahenthrian \& Kasipillai, 2011); financial reporting quality (Hashim, 2012); and cost of debt (Eskandari, 2016), and religious belief impacts capital structure across Shariah and Non-Shariah companies (Hadi, Rehan, Zainudin, \& Hussain, 2018); and earning management (Rahayu, Omar, Rahman, \& Muda, 2018). On the contrary, some researchers adopted national culture dimensions like power distance; individualism; uncertainty avoidance; and masculine to view culture on decisions making of "earning management" (Haniffa, Rahman, \& Ali, 2006); "analysts forecast" (Abdul Wahab, Allah Pitchay, \& Ali, 2015); and "shareholder activism" (Satkunasingam \& Shanmugam, 2006). Therefore, the observations of culture (Ethnicity and Religion) or cultural dimension or combination of two on financial decision making is still prevalent and not limited to Malaysia context.

\section{Culture as Ethnicity and Religion on Decision Making}

The study of culture such as "ethnicity and religion" embedded at informal institutions could influence the decision of firms' capital structure. Hsee and Weber (1999) elaborated that different cultural views and evaluation risk differently in which some are "risk-seeking" and others may be "risk-averse". Hilary and Hui (2009) posited ethnicity and religion could explain "risk-seeking" or "risk-averse" and could have significant effects on corporate decision making. For instance, in a multiracial country such as Malaysia, a study showed that the Chinese have high individualism and low uncertainty avoidance. Whereas, the counterpart Malay ethnic group has low individualism and high uncertainty (Abdul Wahab et al., 2015; Haniffa \& Cooke, 2002; Idris, 2017). However, linking cultural proxy as religion and ethnicity to the capital structure is a rather young and less known research field that can contribute to the traditional finance literature (Nadler \& Breuer, 2019). Thus, there is a lack of study in the way ethnicity and religion could influence their decision on debt and equity financing.

Haniffa and Cooke (2002) investigated the impact of culture, such as religion and ethnicity on financial decisions. Despite Malaysia being a multiracial society, there are only a few studies of proxy culture as religion and ethnicity compared to dimensional cultures such as Power Distance (PD), Individualism (I), Masculine (M), Uncertainty Avoidance (UI), long term orientation (LT), and indulgence. Even though previous research used cultural proxies such as religion and ethnicity to study finance in Malaysia, the constructs are limited to Malay and Non-Malay or Muslim and NonMuslim. Furthermore, none of the previous research conducted investigations of Malay, Chinese, Islam, Buddhism, and Christianity on capital structure decisions. Malaysia being a multiracial society is not suitable to adopt a cultural dimension to explain culture on decision making because it is often too generalized, and religion often has unique faith and belief. In order to discuss the gaps in the literature, most of the findings of prior studies are inconclusive. Hence, investigation of how culture impacts decision making shall focus on sub-culture such as Malay, Chinese, Islam, Buddhism, and Christianity. This study tested the relationship between cultural proxy such as religion and ethnicity on capital structure decisions. The religions are Islam, Buddhism, and Christianity, whereas ethnicity is Malay and Chinese. A total of six hypotheses were developed to test the relationship.

\section{HYPOTHESIS DEVELOPMENT}

The distinctive Malay ethnic group values exhibit collective behavior that becomes an important source of self-esteem. To increase social identity and self-image, Malay ethnic groups continue to enhance the in-group status by discriminating and holding prejudiced views against the out-group. For instance, there are many studies on the ethnicity of Malays compared to other ethnic groups. Interestingly, Malay directors on the board are significantly correlated with the extent of voluntary disclosure. Thus, this suggests that Malays' value of social sensitivity has harmonized governmental requirements to increase voluntary disclosure (Idris, 2017). The Malay directors reportedly have a higher influence on financial reporting quality (Haniffa \& Cooke, 2005).

Hashim (2012) articulated that there are positive relationships between the proportion of Malay directors and forecast error. The finding showed the increase of Malay directors tends to have higher forecast error. And the Malay directors were also found to have significant effects on reducing the agency problem through profound CG practices. These have reduced and minimized the cost of raising funds via debt in the capital of the market (Abdul Wahab et al., 2015). The observations showed Malays' culture and values have a significant impact on capital structure decision, where high uncertainty avoidance, collectivism, and power distance are more risk-averse (Eskandari, 2016) and tend to use more short-term debt supporting the pecking order theory (Gaganis, Hasan, Papadimitri, \& Tasiou, 2019; Li, Griffin, Yue, \& Zhao, 2013). Whereas low long-term orientation is more risk-averse, and Islamic-based countries have a negative impact on corporate risk-taking (El Ghoul \& Zheng, 2016). Hence, the pecking-order theory reiterates that capital structure decisions are organized in a hierarchical pecking order, first being internal sources, second being external debt financing, and third being equity financing. And the hypothesis is stated formally as follows:

Hypothesis 1 (H1): Malay CEO is more risk-averse that negatively correlated with leverage. 
Chinese are also perceived as "being authoritative and monitoring operations" and are associated with high power distance. Similar to Idris (2017), he claimed that the Chinese exhibit a high value of power distance in Malaysian society. This power distance orientation is reflected in the five cardinal relationships governing social interactions in China, described as 'Wu-Lun': the five Confucian relationships "ruler-subject, father-son, brother-brother, husband-wife, friendfriend" (Haniffa \& Cooke, 2002). Moreover, "showing benevolence, relating and communicating" divulge Chinese ethnic groups to have the value of collectivism. Nonetheless, observations showed Chinese are perceived more individualism rather than collectivism which may attribute to the presence of ethnic polarization in the socioeconomic context (Zhang, Song, Hackett, \& Bycio, 2006). Hence, Chinese ethnic values illustrate social identity to exhibit collective behavior that becomes an important source of self-esteem to be materialistic, risk-seeking, visionary, and obedient. This increases Chinese ethnic social identity and self-image to enhance group propaganda by discriminating and going against the outgroup.

Idris (2017) suggested that the Chinese are materialistic, risk-seeking, visionary, obey to family's values, associate with business clans; hence they are said to have low uncertainty avoidance, quite high long-term orientation, and power distance. Similarly, Tan (1984) revealed that the Chinese were significantly more risk-seeking on capital structure decision, therefore, observations showed Chinese has low uncertainty avoidance and collectivism and more risk-seeking (Albaity \& Rahman, 2012; Breuer \& Quinten, 2009). Dimensions also suggested that the Chinese have high power distance and long-term orientation and are more risk-seeking as well (Gaganis et al., 2019; Li et al., 2013). Trade-off theory states that total debt to total equity has a negative impact on firm risk-seeking decisions. Although there are benefits of debts, conversely there are also the costs of debts to be considered as costs increase alongside the increase of the bankruptcy probability for being risk-seeking (Chaleeda et al., 2019). However, according to trade-off theory, the firm trades off between the benefits and costs to optimize debt and equity to use for financing. Hence the hypothesis is stated formally as follows:

\section{Hypothesis 2 (H2): Chinese CEO is more risk-seeking and positively correlated with leverage.}

Studies showed that firms located in counties with higher levels of religiosity are risk-averse (Hilary \& Hui, 2009) and Malaysia is regarded as a relatively religious country (Díez-Esteban, Farinha, \& García-Gómez, 2019). For instance, Malaysia's official religion is Islam, therefore, all the Malay are Muslim by law. Whereas, Chinese practice various faiths like Buddhism and Taoism. On the other hand, Christianity has established itself in many ethnic groups, especially in East Malaysia. Hence, it provides the perfect context to investigate the construct of religion and finance (Hooy \& Ali, 2017).

Islam believes in the concept of a Supreme Being - "Allah the Almighty" (Khalili, 2014), emphasizing the six major Islamic values in Islam, which are accountability, equity, fairness, morality, responsibility, and social justice (Albassam $\&$ Ntim, 2017). The principle of equity and fairness may in turn hinder a Muslim from being competitive where Muslim CEO that follows the principles of Islam may tend to avoid competition with the rivals (Hooy \& Ali, 2017). Hence, Muslims are the antimarket (Guiso, Sapienza, \& Zingales, 2003), likely to hinder competition (Hooy \& Ali, 2017), and moves towards risk aversion (Wilson \& Liu, 2010), which probably lead to low leverage on capital structure decisions. Furthermore, Muslims strive on high accountability and responsibility values to reduce information asymmetry that impacts the selection between internal and external financing such as issues of debt or equity-based on pecking order (Sahudin, Ismail, Sulaiman, Rahman, \& Jaafar, 2019). According to pecking-order theory, capital structure decision is organized in a hierarchical pecking order, with the first being internal sources, second is external debt financing, and third is equity financing. Hence the hypothesis is stated formally as follows:

Hypothesis 3 (H3): Muslim CEO is less risk-seeking and negatively correlated with leverage compared to other faiths.

However, Buddhism believes greed can be eliminated by practicing the eight-fold path of "right views, right resolve, right speech, right action, right livelihood, right effort, right mindfulness, and right concentration". Buddhism does not see anything wrong with wealth gained ethically, but it does see greed and craving for riches as negative and praises contentment as 'the greater wealth" (Hilary \& Hui, 2009). Therefore, misappropriate wealth-seeking may increase pecking-order behavior when a person loads more debt or becomes addicted to debt as an instrument to generate and create more wealth. Consistent with pecking-order theory, greed motivates wealth-seeking behavior and in turn, more debt jeopardizes firm vulnerability and performance. The pecking-order theory reiterates that capital structure decision is organized in a hierarchical pecking order, with the first being internal sources, second is external debt financing, and third is equity financing. Based on trade-off theory, the firm trades off between the benefits and costs to optimize debt and equity to use for financing. Hence the hypothesis is stated formally as follows:

Hypothesis 4 (H4): Buddhism CEO has higher leverage compared to other faiths

There is strong confirmatory evidence that many religious people are more risk-averse with regard to financial risks (Noussair, Trautmann, Van de Kuilen, \& Vellekoop, 2013). It is echoed by Bartke and Schwarze (2008) where religiousness is significant to determine the risk attitudes and religious people are less risk-tolerant. Observations showed that different religious backgrounds have different impacts on corporate risk-taking, where corporate risk-taking is negative for Catholic and positive for firms in Protestant nations (Díez-Esteban et al., 2019). On contrary, Noussair, 
Trautmann, Van de Kuilen, and Vellekoop (2013) posited that Protestant is more risk-averse than Catholic, but acknowledge that robustness of result as Catholics are sometimes more risk-averse under some specifications (Noussair et al., 2013). The findings were consistent with Díez-Esteban et al. (2019) where Catholics are more averse than other faiths like Protestant, making Catholics less tolerant of speculative risk. Religiousness is a significant determinant of risk attitudes. The observation was consistent with the view that risk-averse reduce misappropriation on current asset problems, therefore trade-off theory suggests capital structure reflects how much debt finance and how much equity finance to use by balancing the costs and benefits. Hence the hypothesis is stated formally as follows:

\section{Hypothesis 5 (H5): Christianity CEO has lower leverage compared to Buddhism.}

The influence of culture in formal institutions such as "Shariah and Non-Shariah compliant firms on capital structure decisions was investigated. Alesina and Giuliano (2015) postulated that culture of an informal institution and formal institution such as "policies and regulations" are interrelated, and there is a reciprocal interaction between the two. For example, Islamic culture influences the Malaysian banking industry to introduce Islamic finance-related products such as Islamic Bond (SUKUK), Islamic Fund, and Islamic Stocks (Breuer \& Quinten, 2009). Conversely, Shariah compliance policies imposed by SAC to ensure Shariah Compliant firms conform to Islamic principles and values. However, there is a lack of study that a Shariah-compliant firm could influence their decision on capital structure pursuing trade-off theory and pecking order theory.

Breuer and Quinten (2009) articulated that Islam influences the financing products in Malaysia based on Shariah Principles, for instance, the introduction of Islamic Bond (SUKUK), Islamic Fund, and Islamic Stocks. Previous studies argued that two theories supported the relationship. The theories are pecking order and trade-off theories. However, the findings were not consistent whether Shariah-compliance is better to be explained by pecking-order or trade-off theories. Shariah compliance policies imposed by SAC ensure Shariah Compliant firms conform to Islamic principles and values. However, this study was unsure that a Shariah-compliant firm could influence their decision on capital structure. Hence, investigation of how Shariah-compliance impacts the decision making such as capital structure shall be supported with an anchor theory. To fill the gap, this study tested the relationship between Shariah-compliance on capital structure decisions. Another hypothesis was developed to test the relationship.

Hypothesis 6 (H6): Shariah-compliant firms are negatively correlated with leverage.

\section{MALAYSIA TOP CORPORATION GOVERNANCE PLCS}

This study has five independent variables, namely Ethnicity (CEOETH), Religion (CEOREL), Board Diversity (BODDIV), Board Independence (BODIND), and Shariah compliance (SHACOM), with two control variables including Board Size (BODSIZ) and Foreign Independent Non-Executive Director (FOINED) on capital structure. Table 1 presents the summary of descriptive statistics relating to panel data A (CG winners in 2017 and 2018), and panel data B (Nonwinners). Firstly, the panel data shows a balance in terms of sample size, broad independence, and a number of Shariah compliance PLCs with the BODIND of 0.554 and 0.526 respectively. Secondly, CEOREL is dominated by Muslims at $40.1 \%$, followed by Buddhists at $35.3 \%$, and lastly Christian at $24.1 \%$. Interestingly, Buddhist CEOs are dominant at panel data B, whereas Muslim CEOs are found to be dominant at panel data A. Thirdly, CEOETH shows that there is a substantial degree of dispersion in the distribution. For instance, the Indian and Other CEOs range from a minimum of $4.8 \%$ to a maximum of $81.2 \%$ that consists of Chinese and Malay CEOs with the Chinese CEOs being more dominant than Malay CEOs at 29.6\%. Next, BODDIV (0.374) shows that PLCs are less divergent compared to BODIND (0.540). Furthermore, there are 27 PLCs or $14.4 \%$ have monotonous ethnic board members that are equally spread between Chinese and Malay owned PLCs. Hence, Malaysia PLCs are more focused on Board independence rather than Board diversity partly to fulfil MCCG requirements. Lastly, PLCs have an average BODSIZ of 7.545 members with a lower of 4 broad members to the biggest broad consist of 13 members.

Table 1: Summary of Descriptive Statistic of Winners and Non-Winners

\begin{tabular}{llll}
\hline & Panel Data A & Panel Data B & \\
\hline CEOREL & CG Winner 2017-2018 & Non-Winner & Total \\
\hline Muslim & 42 & 34 & 76 \\
Buddhist & 24 & 42 & 66 \\
Christian & 24 & 21 & 45 \\
Sample (n,N) & 90 & 97 & 187 \\
\hline
\end{tabular}

\section{CEOETH}

Malay

Chinese 


\begin{tabular}{llll}
\hline & Panel Data A & Panel Data B & \\
\hline Others & 3 & 1 & 4 \\
Foreign & 11 & 4 & 15 \\
Sample $(\mathrm{n}, \mathrm{N})$ & 90 & 97 & 187 \\
\hline BODDIV & 0.419 & 0.332 & 0.374 \\
BODIND & 0.554 & 0.526 & 0.540 \\
SHACOM & 68 & 70 & 138 \\
BODSIZ & 8.279 & 6.886 & 7.545 \\
FOINED & 17 & 4 & 21 \\
\hline
\end{tabular}

\section{RESEARCH FRAMEWORK}

This study adopted a longitudinal deductive approach to collect data from 2015 to 2019 . The sample size of this study is 187 Public Listed Corporations (PLCs) that are listed on BURSA's Main board. The sampling frame also excludes PN4, PN17, PLCs in the Finance sector, and CEO that has been appointed in 2019. The sample is built up from 90 PLCs of best practices Corporate Governance winners in 2017 and 2018 to form panel data A; and the other 97 PLCs of nonwinners to form panel data B. Firstly, the census sampling approach will be used to collect data for all Top 100 Corporate Governance winners awarded by Minority Shareholders Watch Group (MSWG) in 2017 and 2018 where the winners have demonstrated outstanding Corporate Governance performance, and followed by random sampling to select another 100 PLCs (non-winners) from BURSA where both panels data balance in term of Board independence and Number of Shariah Compliance PLCs. The study mainly used secondary data collection approaches. Firstly, the CEO's religion is collected from secondary sources such as press interviews, news, events, publications, religion association website, Wikipedia, and social media where the CEO's name was searched in Google search engine. On many occasions, an auxiliary word namely "Religion; Faith; Buddhist; Lotus; Christian; Jesus; Lord; Association; and Persatuan (Malay words of Association)" was included to aid the search results. Secondly, the remaining secondary data were accessed from annual reports, SAC reports, and Corporate Governance winner's databases to analyze a firm's capital structure. The operationalization of the variable begins with Debt/Equity and Debt/Asset ratio as measurements of the dependent variables and is followed by CEO's Religion, Ethnicity, Board Diversity, Board Independence, and Shariah Compliant Status as the independent variables. This research formulated a multivariate regression model to analyze the data based on the Ordinary Least Squares approach.

The practical contribution of this study is the adoptions of NIEs framework to understand how cultural divergence rationality such as CEO's religion and ethnicity interferes on capital structure decision. The approach closes the gap of traditional capital structure theory that emphasises the corporate strategic decision and strives resources towards maximization of shareholder values. Furthermore, the study made significant contributions to explain the relationships of informal (Culture as Ethnicity and Religion) and formal institution (Policies as Shariah compliance) on capital structure.

Technically, the econometric model in this study is also termed as a linear regression model, which was developed to examine capital structure (LEV). The study adopted DA (Cetenak, Cingoz, \& Acar, 2017; Daud, Norwani, Mansor, \& Endut, 2016); and DE (Chaleeda et al., 2019; Hadi et al., 2018) as dependent variables and described LEV to proxy the capital structure. The linear regression function hypothesized that the dependent variables LEV are linearly related to the independent variables. In this study, the independent variables are Ethnicity (CEOETH); Religion (CEOREL); Board Diversity (BODDIV); Board Independence (BODIND); and Shariah compliance (SHACOM) where the linear regression function is widely seen in previous observations on capital structure. The control variables in this study are Board Size (BODSIZ) and Foreign Non-Executive Independent Director (FOINED). For instance, regression function hypothesized capital structure measure as DA on national culture (Cetenak et al., 2017); on a firm's performance (Daud et al., 2016). Capital structure also measures as DE on the firm's value (Chaleeda et al., 2019); and on Shariah Compliance (Hadi et al., 2018). Thus, the approach of linear regression function to link capital structure and explanatory variables are not prevalent.

The objectives of this study are to examine the relationship between culture, shariah compliance, and CG on capital structure, where CEO's religion (CEOREL) and CEO's ethnicity (CEOETH) as culture proxy, and Board Diversity (BODDIV), Board independence (BODIND) as CG proxy. Hence, two multiple regression functions are embarked on to measure the relationship between capital structure. For instance, LEV as dependent variables and CEOREL, CEOETH, BODDIV, BODIND, SHACOM as independent variables and the multiple regression functions is depicted in Equation 1 and 2.

LEVDA $=\beta_{0}+\beta_{1}$ CEOREL $+\beta_{2}$ CEOETH $+\beta_{3}$ BODDIV $+\beta_{4}$ BODIND $+\beta_{5}$ SHACOM $+\beta_{6}$ BODSIZ $+\beta_{7}$ FOINED $+\varepsilon$

Multiple Regression Function for LEV as DA 
Multiple Regression Function for LEV as DE

\section{CONCLUSIONS}

This research explained how culture such as ethnicity and religion impact capital structure decisions (Boubakri \& Saffar, 2016; Roszaini M Haniffa \& Cooke, 2005; Nadler \& Breuer, 2019). Different ethnicity and religion view and evaluation risks differently in which some are "risk-seeking" and others may be "risk-averse" (Hilary \& Hui, 2009). Unlike many culture dimensional studies, this study adopted ethnicity and religion as proxies of culture to explain capital structure decisions. Thus, this study made theoretical contributions to explain how ethnicity and religion impose constraints and incur transaction costs on capital structure decision regarding the Trade-off Theory and Pecking Order Theory. Furthermore, this study included a formal institution to conceptualize the research framework based on NIEs to explain culture on capital structure decisions. This study made a significant contribution to explain the relationships of informal (Culture) and formal institution (Shariah compliance) on capital structure. Furthermore, this study echoed the advocation from Nadler and Breuer (2019) to adopt NIEs as a standardize theoretical framework for future study of cultural finance.

\section{REFERENCES}

Abdul Wahab, E. A., Allah Pitchay, A., \& Ali, R. (2015). Culture, corporate governance and analysts forecast in Malaysia. Asian Review of Accounting, 23(3), 232-255.

Aggarwal, R., Faccio, M., Guedhami, O., \& Kwok, C. C. Y. (2016). Culture and finance: An introduction. Journal of Corporate Finance, (41), 466-474.

Ahern, K. R., Daminelli, D., \& Fracassi, C. (2015). Lost in translation? The effect of cultural values on mergers around the world. Journal of Financial Economics, 117(1), 165-189.

Albaity, M., \& Rahman, M. (2012). Behavioural finance and Malaysian culture. International Business Research, 5(11), 65.

Albassam, W. M., \& Ntim, C. G. (2017). The effect of Islamic values on voluntary corporate governance disclosure. Journal of Islamic Accounting and Business Research.

Alesina, A., \& Giuliano, P. (2015). Culture and institutions. Journal of Economic Literature, 53(4), 898-944.

Bank Negara Malaysia. (2015). Financial Stability and Payment Systems Report 2014. Bank Negara Malaysia.

Bank Negara Malaysia. (2019). Financial Stability and Payment Systems Report 2018. Bank Negara Malaysia.

Bartke, S., \& Schwarze, R. (2008). Risk-averse by nation or by religion? Some insights on the determinants of individual risk attitudes. Some Insights on the Determinants of Individual Risk Attitudes (October 2008). SOEPpaper, (131).

Boubakri, N., \& Saffar, W. (2016). Culture and externally financed firm growth. Journal of Corporate Finance, 41, 502-520.

Breuer, W., \& Quinten, B. (2009). Cultural finance. Available at SSRN 1282068. http://dx.doi.org/10.2139/ssrn.1282068

Cetenak, E. H., Cingoz, A., \& Acar, E. (2017). The Effect of National Culture on Corporate Financial Decisions. In Dinçer H., Hacioğlu Ü. (eds) Risk Management, Strategic Thinking and Leadership in the Financial Services Industry (pp. 355-368). Springer.

Chaleeda, M., Islam, A., Ahmad, T. S. T., \& Ghazalat, A. N. M. (2019). The Effects of Corporate Financing Decisions on Firm Value in Bursa Malaysia. International Journal of Economics and Finance, 11(3). 127-135.

Chu, E.-Y., Lai, T.-S., \& Song, S.-I. (2016). Corporate governance and financial constraints in family controlled firms: Evidence from Malaysia. International Journal of Business and Society, 17(3), 492-446.

Daud, W. M. N. W., Norwani, N. M., Mansor, A. A., \& Endut, W. A. (2016). Does Financing Decision Influence Corporate Performance in Malaysia? International Journal of Economics and Financial Issues, 6(3), 1165-1171.

Díez-Esteban, J. M., Farinha, J. B., \& García-Gómez, C. D. (2019). Are religion and culture relevant for corporate risk-taking? International evidence. BRQ Business Research Quarterly, 22(1), 36-55.

El Ghoul, S., \& Zheng, X. (2016). Trade credit provision and national culture. Journal of Corporate Finance, 41, 475-501.

Eskandari, A. (2016). The effect of corporate governance on the cost of debt capital.

Gaganis, C., Hasan, I., Papadimitri, P., \& Tasiou, M. (2019). National culture and risk-taking: Evidence from the insurance industry. Journal of Business Research, 97, 104-116.

Giannetti, M., \& Yafeh, Y. (2012). Do cultural differences between contracting parties matter? Evidence from syndicated bank loans. Management Science, 58(2), 365-383.

Grinblatt, M., \& Keloharju, M. (2001). What makes investors trade? The Journal of Finance, 56(2), 589-616.

Guiso, L., Sapienza, P., \& Zingales, L. (2003). People's opium? Religion and economic attitudes. Journal of Monetary Economics, 50(1), 225-282.

Hadi, A. R., Rehan, R., Zainudin, Z., \& Hussain, H. I. (2018). Capital structure determinants of shariah and non-shariah companies at bursa Malaysia. Opcion, 34(Special Issue 16), 376-386.

Haniffa, R., Rahman, R. A., \& Ali, F. H. M. (2006). Board, audit committee, culture and earnings management: Malaysian evidence. Managerial Auditing Journal. 21(7), 22.

Haniffa, Roszaini M, \& Cooke, T. E. (2005). The impact of culture and governance on corporate social reporting. Journal of Accounting and Public Policy, 24(5), 391-430.

Haniffa, Rozaini Mohd, \& Cooke, T. E. (2002). Culture, corporate governance and disclosure in Malaysian corporations. Abacus, 38(3), 317-349.

Hashim, H. A. (2012). The influence of culture on financial reporting quality in Malaysia. Asian Social Science, 8(13), 192.

Hilary, G., \& Hui, K. W. (2009). Does religion matter in corporate decision making in America? Journal of Financial Economics, 
93(3), 455-473.

Hofstede, G. (1983). National cultures in four dimensions: A research-based theory of cultural differences among nations. International Studies of Management \& Organization, 13(1-2), 46-74.

Hooy, C.-W., \& Ali, R. (2017). Does a Muslim CEO matter in Shariah-compliant companies? Evidence from Malaysia. Pacific-Basin Finance Journal, 42, 126-141.

Hsee, C. K., \& Weber, E. U. (1999). Cross-national differences in risk preference and lay predictions. Journal of Behavioral Decision Making, 12(2), 165-179.

Idris, A. (2017). Ethnicity And Cultural Values: An Empirical Study Of Malay And Chinese Entrepreneurs In Peninsular Malaysia. Sarjana, 26(1), 22-40.

Khalili, S. (2014). Going global, acting local: effects of cultural dimensions on Glocal marketing in Malaysia. The International Technology Management Review, 4(3), 142-157.

Kroeber, A. L., \& Kluckhohn, C. (1952). Culture: A critical review of concepts and definitions. Papers. Peabody Museum of Archaeology \& Ethnology, Harvard University.

Landa, J. T. (2008). The bioeconomics of homogeneous middleman groups as adaptive units: Theory and empirical evidence viewed from a group selection framework. Journal of Bioeconomics, 10(3), 259.

Li, K., Griffin, D., Yue, H., \& Zhao, L. (2013). How does culture influence corporate risk-taking? Journal of Corporate Finance, 23, $1-22$.

Maelah, R., Aman, A., Amirruddin, R., Sofiah, Auzair, M., \& Hamzah, N. (2012). Accounting outsourcing practices in Malaysia. Journal of Asia Business Studies, 6(1), 60-78.

Mahenthrian, S., \& Kasipillai, J. (2011). Influence of ownership structure, corporate governance, and culture on tax policy: evidence from Malaysia. Corporate Governance, and Culture on Tax Policy: Evidence from Malaysia. Emerging Markets: Theory \& Practice eJournal.

Mallisa, M., \& Kusuma, H. (2017). Capital structure determinants and firms' performance: Empirical evidence from Thailand, Indonesia and Malaysia. Polish Journal of Management Studies, 16(1): 154-164.

Nadler, C., \& Breuer, W. (2019). Cultural Finance as a research field: an evaluative survey. Journal of Business Economics, 89(2), $191-220$.

Newman, A., Gunessee, S., \& Hilton, B. (2012). Applicability of financial theories of capital structure to the Chinese cultural context: A study of privately owned SMEs. International Small Business Journal, 30(1), 65-83.

Noussair, C. N., Trautmann, S. T., Van de Kuilen, G., \& Vellekoop, N. (2013). Risk aversion and religion. Journal of Risk and Uncertainty, 47(2), 165-183.

Rahman, R.A., Omar, N., Rahman, A., \& Muda, R. (2018). Islamic ethical values of corporate top leadership and real earnings management. International Journal of Law and Management, 60, 869-884.

Sahudin, Z., Ismail, Z., Sulaiman, S., Rahman, H. A., \& Jaafar, M. N. (2019). Capital Structure Determinants of Shariah-compliant Firms. Journal of Emerging Economies \& Islamic Research, 7(1), 65-75.

Satkunasingam, E., \& Shanmugam, B. (2006). The consequences of culture on shareholder activism in Malaysia. Journal of Applied Management Accounting Research, 4(1), 45.

Spencer-Oatey, H., \& Franklin, P. (2012). What is culture. A Compilation of Quotations. GlobalPAD Core Concepts, 1-22.

Tan, C. B. (1984). National Culture and National Integration. Aliran Monthly.

Williamson, O. E. (1993). Transaction cost economics and organization theory. Industrial and Corporate Change, 2(2), $107-156$.

Williamson, O. E. (2000). The new institutional economics: taking stock, looking ahead. Journal of Economic Literature, 38(3), 595613.

Wilson, J. A. J., \& Liu, J. (2010). Shaping the halal into a brand? Journal of Islamic Marketing. 1(2), 107-123.

Zhang, K., Song, L. J., Hackett, R. D., \& Bycio, P. (2006). Cultural boundary of expectancy theory-based performance management: A commentary on DeNisi and Pritchard's performance improvement model. Management and Organization Review, 2(2), 279294.

\section{ACKNOWLEDGEMENT}

Firstly, I would like to express my sincere gratitude to my advisor Dr. Chu Ei Yet for the continuous support of my DBA study and related research, for his patience, motivation, and immense knowledge. His guidance helped me in all the time of research and writing of this thesis. I could not have imagined having a better advisor and mentor for my DBA study. Besides my advisor, I would like to thank the rest of my thesis committee: Prof. Dr. Azlan Amran, Prof. Dr. Nabsiah Abdul Wahid, and Associate Prof. Dr. Ellisha Nasruddin, for their insightful comments and encouragement, but also for the hard question which inspired me to widen my research from various perspectives. Moreover, in completing of the thesis, I had to thank lecturers and facilitators that thought and guide me in all core modules, who deserve my greatest gratitude; Prof. Dr. Siti Nabiha Abdul Khalid, Prof. Dr. Sofri Yahya, Dr. Noor Fareen Abdul Rahim, Ir. Dr. Rajendran Muthuveloo, Prof. Dato' Dr. Ruhani Ali, Dr. Chu Ei Yet, Associate Prof. Dr. Junaimah Jauhar, Dr. Teoh Ai Ping, and Dr. Yashar Salamzadeh. My sincere thanks also go to the staffs of GSB who provided me an opportunity to join the DBA program, and the USM Library who gave access to the laboratory and research facilities. Without their precious support it would not be possible to conduct this research. 

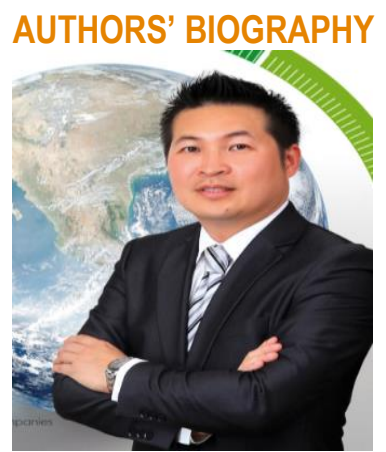

Louis holds a Postgraduate Diploma in Marketing from Chartered Institute of Marketing (UK). He also has Master of Business Administration degree from University of Portsmouth (UK). Now he is pursuing his DBA Doctor of Business Administration in Universiti Sains Malaysia (USM).

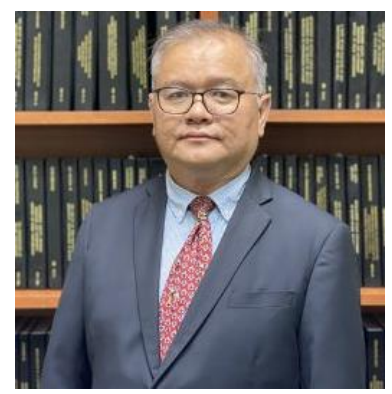

Dr Chu Ei Yet is a senior lecturer at the Graduate School of Business, Universiti Sains Malaysia. His teaching and research interests focus on corporate finance and corporate governance. 